\title{
A review of practical issues related to the diseases of the nail unit useful for doctors (including non-dermatologists)
}

\author{
Przegląd przydatnych dla lekarzy (także niedermatologów) praktycznych zagadnień \\ związanych ze schorzeniami aparatu paznokciowego
}

\author{
'Chair and Clinic of Dermatology, Jagiellonian University Medical College, Krakow, Poland \\ ${ }^{2}$ Department of Physiotherapy, Faculty of Health Sciences, Jagiellonian University Medical College, Krakow, Poland \\ ${ }^{3}$ J. Dietl Specialist Hospital in Krakow, Krakow, Poland \\ ${ }^{4}$ Department of Allergology and Pneumology, Institute of Tuberculosis and Lung Disorders, Jan and Irena Rudnik Field Division, Rabka-Zdrój, Poland; Institute of Health Sciences, \\ Cosmetology, Podhale State College of Applied Sciences in Nowy Targ, Nowy Targ, Poland \\ Correspondence: Andrzej Jaworek, MD, PhD, Chair and Clinic of Dermatology, Jagiellonian University Medical College, Kopernika 50, 31-501 Krakow, Poland, tel.: +48 12 42486 62, e-mail: andrzej.jaworek@uj.edu.pl
}

Abstract The human nail unit is a highly specialised, keratinised structure belonging to the group of skin appendages. It performs many important functions necessary to maintain homeostasis, such as protection of the distal phalanx against damages or stabilisation of the fingertips. Human nail unit is formed by the nail plate and the proximal nail fold, lateral nail folds, nail matrix, nail bed and hyponychium. Human nail unit diseases are often diagnosed with delay, mainly due to anatomical conditions, but also due to understating the problem not only by the patients themselves, but also by doctors. Changes within the human nail unit are a frequent component of many dermatoses or separate disease entities. The main disturbances associated with pathologies within the nail matrix include the Beau lines (transverse pits indicating temporary disruption of the nail plate growth), onychomadesis (nail shedding), onychorrhexis, nail pitting, koilonychia (spoon nails) or trachonychia (sandpapered nails). The group of diseases associated with disorders of the nail bed includes onycholysis (loss of communication between the nail plate and the nail bed), subungual hyperkeratosis, apparent leukonychia (associated with the swelling of the nail bed) and subungual petechiae. The article also presents selected nail diseases associated with the deposition of dye (including melanonychia), some congenital disorders of the nail unit (such as, for example, malalignment of the great toenail or nail-patella syndrome) and selected manifestations of systemic diseases within the human nail unit. Getting familiar with the correct onychological nomenclature and presented issues will certainly facilitate establishing a dialogue between specialists in skin diseases and general practitioners.

Keywords: human nail unit, nail matrix diseases, disorders within the nail bed, congenital nail disorders

Streszczenie Aparat paznokciowy (narząd paznokciowy) to wysoce wyspecjalizowana, skeratynizowana struktura należąca do grupy przydatków skóry. Pełni on wiele istotnych funkcji niezbędnych do utrzymania homeostazy, takich jak ochrona paliczka dystalnego przed uszkodzeniami czy stabilizacja opuszek palców. Aparat paznokciowy tworzą płytka paznokciowa oraz proksymalny wał paznokciowy i wały boczne, macierz paznokcia, łożysko paznokcia i obrąbek (hyponychium). Schorzenia aparatu paznokciowego rozpoznawane są nierzadko z opóźnieniem, przede wszystkim ze względu na warunki anatomiczne, lecz również z powodu bagatelizowania problemu nie tylko przez samych pacjentów, ale także przez lekarzy. Zmiany w obrębie aparatu paznokciowego są częstym elementem składowym wielu dermatoz lub stanowią osobne jednostki chorobowe. Do głównych zaburzeń związanych z patologiami w obrębie macierzy paznokcia należą linie Beau (poprzeczne zagłębienia świadczące o chwilowym zaburzeniu wzrostu płytki paznokciowej), onychomadeza (spełzanie płytek paznokciowych), onychorrhexis, nail pitting (paznokcie dziurkowane), koilonychia (paznokcie łyżeczkowate) czy trachonychia (szorstkość paznokci). W grupie zaburzeń związanych z zaburzeniami w obrębie łożyska paznokcia znajdują się onycholiza (utrata łączności pomiędzy płytką paznokciową a łożyskiem paznokcia), rogowacenie podpaznokciowe, przejściowa leukonychia (związana z obrzękiem łożyska paznokcia) oraz wybroczyny podpaznokciowe. W artykule przedstawione zostały także wybrane choroby paznokci związane z odkładaniem się barwnika (m.in. melanonychia), niektóre wrodzone schorzenia aparatu paznokciowego (takie jak np. wrodzone przemieszczenie paznokcia palucha czy zespół paznokieć-rzepka) i wybrane manifestacje schorzeń ogólnoustrojowych w obrębie aparatu paznokciowego. Zapoznanie się z prawidłowym nazewnictwem onychologicznym oraz przedstawionymi informacjami ułatwi z całą pewnością nawiązanie dialogu pomiędzy specjalistami chorób skóry a specjalistami medycyny rodzinnej. 


\section{INTRODUCTION}

$\mathrm{T}$ he human nail unit (HNU) is a unique, specialised, highly keratinised structure belonging to the group of skin appendages. The role of HNU in maintaining homeostasis under physiological conditions is often underestimated. The key functions of HNU include, among other things, protection (the nail plate protects distal parts of limbs, which are particularly prone to injury), aesthetics (neat, often adorned nails are considered an element influencing the perception of an individual), a function related to the biomechanics of the foot (stabilisation of the fingertips), and manipulation (HNU facilitates tactile discrimination of objects) $)^{(1,2)}$. Diseases of the HNU have been known for a long time in dermatology, with a Polish expert - professor Jan Alkiewicz from Poznań, who was first to use the terms onychotillomania, trachonychia and spriggy network, standing out among the leading onychologists ${ }^{(3,4)}$.

\section{FUNCTIONAL ANATOMY OF THE NAIL}

The nail unit is composed of the nail plate and four main elements: proximal nail fold (PNF) and lateral folds, nail matrix, nail bed and the hyponychium. Both the matrix and the bed produce the nail plate (hard, high in alpha-keratins, the so-called hard keratins, elastic, resistant to physical and chemical factors, whose hardness increases with age). The nail folds frame the nail plate on three sides. Their key role is to determine the direction of its growth. The eponychium is a band of stratum corneum, which connects the dorsal surface of the plate with the nail fold, sealing this connection. Damage to the eponychium affects the growth of the plate, while inflammation of the nail fold leads to abnormalities of the eponychium ${ }^{(1,5)}$. The nail matrix is located above the distal phalanx bone (there is a connection between the matrix - through a tendon - and the region of the distal interphalangeal joint, which accounts for the overlapping nail and joint involvement in psoriasis), and is composed of two parts: proximal and distal. Lateral parts of the nail matrix are located within the furrows of the lateral nail folds, which may result in the occurrence of sharp keratoid spikes produced by residual matrix in the event of an inaccurate procedure of destruction of the nail matrix ${ }^{(1,5,6)}$. Since most of the nail plate $(80 \%)$ is produced by the proximal matrix, procedures causing damage to this part of the nail (e.g. specimen collection) are associated with the risk of permanent plate deformity. Matrix cells proliferate from the basophilic basal layer and pass through the eosinophilic cubicle layer along the nail axis, forming a compact tile-like structure composed of onychocytes. Melanocytes (about $6.6 / \mathrm{mm}$ ), which require a particularly strong stimulus to produce the pigment and are clinically silent in Celtic individuals, therefore the presence of linear discolourations (longitudinal melanonychia) requires particular vigilance (differentiation with melanoma!), are mainly located in the distal matrix ${ }^{(5,7)}$. The nail bed is a soft, thin (no adipose tissue - the risk of osteomyelitis of the distal phalanx in the event of bacterial infection) structure extending from the distal margin of the lunula up to the eponychium, which contains no melanocytes. Epidermal ridges are particularly pronounced here, which allows attaching the nail plate to the finger. Macroscopically, the visible difference between the matrix region and the nail bed consists in a change in the colour (the pink colour is due to the presence of multiple, linearly arranged blood vessels) and a folded surface ${ }^{(1,5,8)}$.

Based on the generally accepted classification system proposed by Tosti and Piraccini, further parts of the paper will discuss the correlation between the level of HNU defect and clinical manifestation of a given disease ${ }^{(8)}$.

\section{DISORDERS ASSOCIATED WITH NAIL MATRIX PATHOLOGY}

\section{Beau's lines}

Beau's lines (also known as Beau-Reil lines; Johann Christian Reil, 1796; Joseph Honoré Simon Beau, 1846) are transverse (or parallel) depressions in the nail plate, which indicate temporary (transient) disturbance of nail growth. The pathophysiology of the symptom is associated with temporary arrest of matrix activity (onychomadesis occurs if the process lasts more than 1-2 weeks). Physiological Beau's lines occur in infants around the age of 5 weeks due to birth-related stress. Beau's lines occur in many diseases (e.g. zinc deficiency, Kawasaki disease, erythroderma, pyogenic granuloma). An attempt to assess at which point the process leading to nail matrix disorders occurred (considering the fact that adult fingernails and toenails grow at a rate of $3 \mathrm{~mm} /$ month and $1 \mathrm{~mm} /$ month, respectively) is an interesting element of onychological diagnosis. It therefore seems that Beau's lines may indicate a disorder that occurred 6 months (thumb) or even 2 years (the hallux) earlier.

Beau's lines have been also described in certain population groups, such as members of expeditions to the Himalayas (the so-called Everest nails - a result of altitude-related hypoxia), divers, etc. ${ }^{(3,89)}$. Lee and Yun shared a very interesting observation on the relationship between wearing a sling and the occurrence of Beau's lines ${ }^{(10)}$. Washboard nails are the result of habitual irritation (pushing away, pressing, etc.) of the proximal nail fold with multiple Beau's lines (and often with a depression in the middle of the nail known as serrated koilonychia).

\section{Onychomadesis}

Onychomadesis (defluvium unguium) is a continuum of pathophysiological phenomena associated with transient arrest of the nail matrix function. This symptom is characterised by complete separation of the nail plate from the nail matrix, with (at least initially) maintained adherence to the nail bed. Onychomadesis is associated with multiple 


\begin{tabular}{|l|l|}
\hline $\begin{array}{l}\text { A group of diseases } \\
\text { (medical problems) } \\
\text { causing onychomadesis }\end{array}$ & Conditions \\
\hline Idiopathic onychomadesis & \\
\hline Autoimmune diseases & Alopecia areata, pemphigus vulgaris \\
\hline Major medical problems & $\begin{array}{l}\text { Stevens-Johnson syndrome } \\
\text { Mycosis fungoides } \\
\text { Kawasaki disease } \\
\text { Erythroderma }\end{array}$ \\
\hline Infectious diseases & $\begin{array}{l}\text { Chickenpox } \\
\text { Malaria } \\
\text { Pertussis } \\
\text { Diphtheria } \\
\text { Hand, foot, and mouth disease (HFMD) } \\
\text { Scarlet fever }\end{array}$ \\
\hline Congenital diseases (syndromes) & $\begin{array}{l}\text { Heimler syndrome } \\
\text { Idiopathic sporadic onychomadesis } \\
\text { Hyper-lgM syndrome }\end{array}$ \\
\hline Injuries & $\begin{array}{l}\text { Manicure } \\
\text { Injury to the nail unit } \\
\text { Wrist fracture } \\
\text { Long-term immobilisation } \\
\text { Decompression sickness }\end{array}$ \\
\hline
\end{tabular}

Tab. 1. Causative factors of onychomadesis ${ }^{(11,12)}$

conditions (Tab. 1) ${ }^{(11,12)}$. Casting off the nail may be also caused by medications, such as chemotherapeutic agents (capecitabine, doxorubicin, cytosine arabinoside, etoposide), anticonvulsants (carbamazepine, valproic acid), penicillin, lithium, azithromycin, retinoids ${ }^{(11)}$.

Onychomadesis is particularly often described in the course of hand-foot-mouth disease (HFMD), caused by a group of human enteroviruses belonging to the Picornaviridae family. Coxsackievirus A16 (CVA 16) and enterovirus 7 (EV 71) are among the most common HFMD serotypes. The relationship between proximal separation of the nail plate and viral infection (usually about 4-10 weeks after infection) was first observed in 2010. Since then, this relationship has been confirmed by many literature reports. In 2019, Chiu et al. published their paper on the discovery of a new type of virus known as Coxackievirus A6 (CVA6), which was isolated from the nail region in three (out of 11) patients with onychomadesis secondary to HFMD, using the reverse-transcriptase polymerase chain reaction (RT-PCR). The authors emphasised that only some (particularly virulent) viral strains are able to affect the region of nail matrix in the course of HFMD.

\section{Onychorrhexis}

Onychorrhexis is a term describing shallow, linear, longitudinal ridges (grooves) on the dorsal surface of the nail plate, which vary in depth and cause thinning (brittleness) of the nail plate and increased longitudinal fragility ${ }^{(14)}$. The lesions may reach the free edge of the plate, which results in the castle battlement sign or the crenellated sign. Onychorrhexis is probably associated with damage to the nail matrix in the course of, among other things, lichen planus, injuries, distal circulatory disorders and subungual tumours (mass effect) ${ }^{(15)}$.

\section{Nail pitting}

Nail pitting (nail perforation, thimble-like pitting of nails) refers to superficial depressions in the dorsal nail plate with varying morphology and distribution. The lesions occur as a result of abnormal keratinisation of the proximal nail matrix. Clusters of parakeratotic cells within the stratum corneum corneocytes are a histopathological determinant of the disorder. Initially, the parakeratotic cells adhere to the surface (they can be seen in the proximal plate), and then, as the plate grows, they slough off leaving pits (resembling a thimble). Nail pitting usually involves fingernails, and the affected nails grow faster than the healthy ones. It seems that inflammatory cells from the region of the proximal nail fold may be involved in this process due to the close contact between its ventral portion and the nail matrix. Thimble-like nails may be observed in many different dermatological conditions (Tab. 2), and may be a useful diagnostic indicator due to the depth and location of pits $^{(16)}$. Irregular, shallow pits most often suggest psoriasis (the symptom may be of key importance in e.g. suspected psoriatic arthritis, in the absence of other dermal signs of the disease). In alopecia areata, pitting is described as geometric, i.e. there are many superficial pits regularly arranged (along transverse and longitudinal lines) on the nail plate. In contact dermatitis, pits are very irregular and associated with crossridging ${ }^{(16)}$. Elkonyxis is a rare symptom, which begins with a deep nail plate depression in the region of lunula, and progressively moves distally with the growth of the nail. Elkonyxis was reported in patients with syphilis, reactive arthritis, and as an adverse reaction of systemic retinoid therapy ${ }^{(17)}$. Thimble-like pitting of nails of fingers 4 and 5, refereed to as the Rosenaus depression, may be a symptom of diabetes ${ }^{(16,18)}$.

\section{Koilonychia}

Koilonychia (also known as spoon nails; Greek: koilos hollow) refers to the thinning of the nail plate with abnormal convexity, i.e. with nails shaped like a spoon, with a central depression and elevated lateral margins. Fingernails rather than toenails are more likely to be involved. Physiological koilonychia of toenails is seen in children. The pathogenesis of the disease is unknown. According to one

\begin{tabular}{l}
\hline Diseases often accompanied by thimble-like nails: \\
- Psoriasis \\
- Albinism \\
- Alopecia areata \\
- Haemodialysis, chronic kidney failure \\
- Contact dermatitis \\
- Lichen planus \\
- Reactive arthritis \\
\hline Diseases less often accompanied by thimble-like nails: \\
- Pemphigus vulgaris \\
- Sarcoidosis \\
- Dermatomyositis \\
- Secondary syphilis \\
- Chronic inflammation of nail folds \\
- Pustular psoriasis
\end{tabular}

Tab. 2. Causes of thimble-like nails $^{(16)}$ 


\begin{tabular}{|c|c|c|}
\hline $\begin{array}{l}\text { Congenital } \\
\text { koilonychia } \\
\text { (an element of } \\
\text { genodermatoses) }\end{array}$ & $\begin{array}{l}\text { Acquired koilonychia } \\
\text { (in the course of other } \\
\text { diseases) }\end{array}$ & $\begin{array}{l}\text { Idiopathic } \\
\text { koilonychia }\end{array}$ \\
\hline $\begin{array}{l}\text { - Nail-patella } \\
\text { syndrome } \\
\text { - LEOPARD syndrome } \\
\text { - Gottron syndrome } \\
\text { (acrogeria) } \\
\text { - Gorlin-Goltz } \\
\text { syndrome } \\
\text { - Ectodermal dysplasia } \\
\text { with anhidrosis } \\
\text { - Nezelof syndrome } \\
\text { - Pigment deficiency }\end{array}$ & $\begin{array}{l}\text { Dermatological diseases: } \\
\text { - Lichen planus } \\
\text { - Psoriasis } \\
\text { - Trachonychia } \\
\text { - Scleroderma } \\
\text { - Alopecia areata } \\
\text { - Lupus erythematosus } \\
\text { Cardiac and haematological } \\
\text { diseases: } \\
\text { - Iron deficiency anaemia } \\
\text { - Polycythemia vera } \\
\text { - Haemochromatosis } \\
\text { - Coronary artery disease } \\
\text { - Primary amyloidosis } \\
\text { Infectious diseases: } \\
\text { - Onychomycosis } \\
\text { - Syphilis } \\
\text { - Scabies } \\
\text { Endocrine diseases: } \\
\text { - Hypothyroidism/ } \\
\text { hyperthyroidism } \\
\text { - Diabetes } \\
\text { - Acromegaly } \\
\text { Erythropoietin-producing } \\
\text { tumours } \\
\text { Carpal tunnel syndrome } \\
\text { Traumatic and occupational } \\
\text { koilonychia }\end{array}$ & \\
\hline
\end{tabular}

Tab. 3. Classification of koilonychia(19)

hypothesis, koilonychia is due to impaired microcirculation and the resulting trophic changes within the distal matrix ${ }^{(19)}$. According to another hypothesis, hyperkeratosis of the nail bed (e.g. in psoriasis, onychomycosis) causes mechanical compression on the distal matrix, which results in spoonshaped nails. The bead test, which involves placing a bead on the nail to check whether it stays on the plate, is a simple tool for confirming the diagnosis ${ }^{(20)}$. Koilonychia may coexist with many diseases (Tab. 3$)^{(19)}$.

\section{Trachyonychia}

Trachyonychia (nail roughness, sandpaper nails) was first described in 1950. The term twenty nail dystrophy (TND), which refers to an idiopathic, acquired trachyonychia involving all nails, was proposed by Hazelrigg et al. in $1977^{(3)}$. Both terms are used interchangeably in onychological literature, which seems inadequate due to the variety of diseases that may lead do TND (also without the features of trachyonychia itself). The nail plate (either thickened or thinned) presents with longitudinal ridging, with thickened and ragged cuticle ${ }^{(8)}$. In 1981, Robert Baran, one of the most prominent experts in nail diseases, distinguished two types of trachyonychia:

- opaque trachyonychia - the most common form, more pronounced variant of the symptom, with thinning and brittleness, excessive longitudinal parallel ridging and fine scales covering the nail surface (compared to a sandpapered surface), disturbing the transparency of the plate;
- shiny trachyonychia - a less common and diagnostically more challenging variation, where the nails maintain their shiny surface, and with the presence of multiple, linear, shallow, geometrically oriented surface defects (pits) that reflect the light.

Trachyonychia usually involves fingernails and overlaps with koilonychia and longitudinal split of the free margin of the nail plate (onychoschisis). Fissures or brittleness are not typically seen in trachyonychia. According to a hypothesis put forward by Antonella Tosti, the condition is a manifestation of inflammation within the nail matrix (the proximal portion) and the ventral surface of the nail fold. Opaque trachyonychia is seen in more severe inflammation, while the shiny form is observed in less severe cases $^{(21,22)}$.

\section{DISORDERS ASSOCIATED WITH PATHOLOGIES OF THE NAIL BED}

\section{Onycholysis}

Onycholysis is a symptom involving detachment of the nail plate (most often the distal part) from the nail bed. The white area usually seen under the plate is associated with the presence of air in the space above the nail bed. For practical reasons, onycholysis can be classified as fingernail onycholysis (more common in women) and toenail onycholysis. Undoubtedly, nail unit injuries, which cause minimal clinical symptoms, but are later extended by the patients themselves, are the most common aetiological factor of both processes. In such cases, the process of onycholysis is a classic example of induced (artificial) dermatosis. Extended onycholysis is subject to secondary contamination by patient's own bacterial flora (e.g. gastrointestinal yeast-like fungi). Other causative factors of fingernail onycholysis include drug-related phototoxic reactions (including capecitabine, tetracyclines, 5-fluorouracil, griseofulvin, olanzapine, oral contraceptives). Interestingly, the shape of the involved plate area is similar to the proximal nail fold. Less common causes of fingernail onycholysis include eczema reactions (contact allergic and non-allergic dermatitis), yellow nail syndrome, pellagra, subungual pustular psoriasis $^{(8,23)}$.

In rare cases, fingernail and toenail onycholysis may be due to very rare and serious conditions (e.g. Langerhans cell histiocytosis), as confirmed by Aghazadeh et al. ${ }^{(24)}$.

\section{Subungual keratosis}

Accumulation of keratotic material in the nail bed and the hyponychium region most often occurs in the course of inflammatory skin conditions (e.g. psoriasis, contact dermatitis), leading to detachment of the plate from the bed and its elevation ${ }^{(8)}$. Subungual keratosis may also represent the first symptom of nail unit squamous cell carcinoma (NUSCC), the most common nail unit cancer, and Bowen's disease of 
the nail unit. The lesions are more common in middle-aged and older men, and are asymmetrical (they most often involve the thumb, fingers 2 and 3 of the dominant hand and the hallux). Symptoms suggesting NUSCC within a persistent hyperkeratotic lesion (which may resemble a viral wart) include purulent discharge, bleeding and unpleasant odour $^{(25)}$.

\section{Apparent leukonychia}

Apparent leukonychia is associated with nail bed oedema. A characteristic feature of this symptom is that the whiteness does not move distally with the growth of the nail and disappears after compression (transparency of the plate itself is maintained ${ }^{(26)}$. Three types of apparent leukonychia have been distinguished:

- Muehrcke's nails (Muehrcke, 1956) - white transverse bands parallel to the lunula, observed in hypoalbuminaemia (nephrotic syndrome, the symptom is reversible with a rise in serum albumin) and as an adverse effect of chemotherapy ${ }^{(26)}$;

- Terry's nails (Terry, 1954) - whitening of the entire nail plate except for the distal (1-2 $\mathrm{mm}$ ) band of the free nail plate margin (which is sometimes described as a brown band due to telangiectasia in the nail bed), observed in patients with cirrhosis, renal failure, congenital heart disease and as a variant of normal ${ }^{(27)}$;

- Half-and-half nails (Bean, 1963); Lindsay's nails (Lindsay, 1963) - apparent leukonychia involving the proximal half of the nail plate; a symptom seen in renal failure and as a variant of normal ${ }^{(28)}$.

\section{Subungual ecchymosis}

Subungual ecchymoses (Sir Thomas Horder, 1920) are reddish-brown (proximal) or purple-black (distal; the initial homogeneous red or purple colour changes and moves distally with the growing nail plate) and longitudinal (along the capillaries in within the nail bed) lesions. Onychoscopy shows well-circumscribed and relatively unstructured foci of globules, spots, dots and bands. Most subungual ecchymoses are associated with injuries and microinjuries, but they may also occur in psoriasis, onychomycosis, AP tumours (e.g. onychomatricoma), and as an adverse effect of therapy (kinase inhibitors). Particular attention should be paid to sudden, massive proximal subungual ecchymoses, which may (rarely) indicate serious systemic conditions, such as endocarditis (Janeway lesions, Osler's node, Roth spots), vasculitis, antiphospholipid syndrome, and trichinellosis ${ }^{(29)}$.

The presence of red, linear ecchymoses compared to comets (which sometimes become better visible upon nail plate compression, are wider in the "head," i.e. distal, region and narrower in the "tail," i.e. proximal, region), and surrounded by a light rim (red comet sign), may be useful in the di-

\begin{tabular}{|l|l|}
\hline Type & The most common causes \\
\hline Melanonychia & Injury, ethnic, medications, lentigo, nevus \\
\hline Leukonychia & $\begin{array}{l}\text { Subungual tumour, skin diseases, systemic } \\
\text { diseases }\end{array}$ \\
\hline Red nails (erythronychia) & Subungual tumour \\
\hline Green nails (chloronychia) & Bacterial infection \\
\hline Blue nails & Medications \\
\hline Yellow nails & Skin diseases, systemic diseases \\
\hline
\end{tabular}

Tab. 4. Classification of chromonychia based on nail colour and the most common causes $^{(31,32)}$

\section{SELECTED NAIL DISEASES ASSOCIATED WITH PIGMENT DEPOSITION}

Chromonychia is an abnormality in the colour of the nail plate or the subungual tissue. This symptom is often a diagnostic hint for skin and systemic diseases, drug reactions, cancer and infections. The most common causes of chromonychia are summarised in Tab. $4^{(31,32)}$.

\section{Melanonychia}

Longitudinal melanonychia is a brown, black or grey band running along the long axis of the nail, from the cuticle to the free nail margin. Most often it is the result of deposition of melanin in the nail plate by melanocytes located in the basal layer of the nail matrix, but (in rare cases) it may be also caused by a haematoma or fungal infection. Histologically, longitudinal melanonychia may be caused by melanocytic activation (hypermelanosis), melanocytic hyperplasia (lentigo; a benign proliferative process) or, most importantly, melanoma of the nail unit. An increased amount of melanin (without an increase in the number of melanocytes) indicates hypermelanosis and is common in people of African or Asian descent. Matrix nevi are usually complex and are the most common cause of melanonychia in children ${ }^{(33)}$. Melanoma of the nail unit is the most dangerous cause of melanonychia. It is rare in Caucasians, and more common in Asians (10-23\%) and African Americans (25\%). According to Tosti and Piraccini ${ }^{(8)}$, lesions involving a single finger (most often the thumb and the hallux) in patients aged between 50 and 70 years require particular oncological vigilance. A band of melanonychia should be assessed for melanoma, especially if the lesion in dark red and $3-4 \mathrm{~mm}$ in width. The features of subungual melanoma include the ability to destroy the nail plate and the Hutchinson's sign (the presence of pigment in the periungual tissue). Each suspected lesion requires dermatological consultation with dermatoscopic examination (onychoscopy) and, most often, removal of the nail plate with a biopsy of the nail unit.

\section{Chloronychia}

Chloronychia (green nails) is an infection of the nail unit most often caused by Pseudomonas aeruginosa, less commonly by other fungal or bacterial species. It is characterised 
by a triad of symptoms: green discolouration of the nail plate (due to bacterial pigments: pyocyanin - blue-green, pyoverdine - yellow-green), proximal chronic paronychia and disto-lateral onycholysis. Hand exposure to water, detergents, soaps, microtraumas, and onychotillomania are factors predisposing to infection ${ }^{(34,35)}$.

\section{SELECTED CONGENITAL CONDITIONS OF THE NAIL UNIT}

\section{Congenital malalignment of the great toenails}

Congenital malalignment of the great toenails (CMGT) is a dystrophic condition described as lateral deviation of the long axis of the nail plate relative to the long axis of the distal phalanx. Three main forms of CMGT have been distinguished: traumatic (injury to the nail matrix), iatrogenic (due to medical procedures within the nail, such as biopsy), and congenital ${ }^{(36)}$. The congenital variant usually occurs in infancy or early childhood (in up to $1-2 \%$ of the population!). Late onset is very rare. The characteristic lateral deviation of the long axis of the nail plate is accompanied by onychodystrophy, when the nail plate has an oyster-like appearance (grey-brown, thickened and deeper transverse ridges). Sometimes the plate may have a triangular shape. The aetiopathogenesis of CMGT is unknown. Both genetic and non-genetic factors, such as uneven growth of the nail, lateral pulling of the proximal nail plate by the extensor tendons of the big toe, mechanical compression due to excessively tight footwear or intensive activity increasing pressure on the distal part of the big toe (dancing), may play an important role in this process. Spontaneous resolution by the age of 10 years is seen in about $50 \%$ of cases ${ }^{(36,37)}$.

\section{Congenital hypertrophy of the lateral nail folds of the hallux}

Congenital hypertrophy of the lateral nail folds of the hallux is characterised by hypertrophic lateral nail folds, which partially cover the nail plate. The lesions are usually evident already at birth or in early infancy in the form of usually symmetrical and bilateral hypertrophic thickened folds (most often) on the medial edges of the nail fold. Although the condition is often asymptomatic, ingrown nail plates (inflammation and pain) may be sometimes observed. Differential diagnosis should include periungual soft tissue fibroma and paronychia (especially in the case of acute inflammation). The lesions usually resolve spontaneously within a few to several dozen months ${ }^{(38)}$.

\section{Racquet nails}

The term racquet nails (racquet thumbs; brachyonychia; 1926) refers to a flattened nail plate, which usually results from the malformation of the underlying bone and the surrounding tissues. It is usually bilateral. The nails present with increased transverse dimension in relation to the longitudinal dimension and flattened nail plates. Two forms of brachyonychia have been distinguished, i.e. congenital (genetic) and acquired (associated, among other things, with hyperparathyroidism) ${ }^{(39)}$. Congenital brachyonychia is associated with premature arrest of growth of distal phalanges of the thumb (longitudinal growth). Simultaneous widening of the phalanx and increase in its thickness result in the widening of the nail unit. The distal part of the thumb and its nail plate become shorter. Brachyonychia is inherited as an autosomal dominant trait. It may be an isolated defect or accompany complex genetic syndromes, such as the trichorhinophalangeal syndrome (TRPS) ${ }^{(39,40)}$.

\section{Nail-patella syndrome}

Nail-patella syndrome (hereditary osteoonychodysplasia, onychoosteodysplasia, Turner-Kieser syndrome, Fong disease) is an autosomal dominant disorder caused by a mutation in the $L M X 1 B$ gene. Its pathognomonic symptoms include a small, residual or no patella, dysplastic or absent fingernails and toenails, dysplasia of the elbow area and calcification of the iliac horns. The $L M X 1 B$ gene is responsible, among other things, for limb formation, differentiation of posterior eyeball cells and the development of some of the neuron groups in the central nervous system. Mutations within this gene may also affect renal function, which determines prognosis in patients with this disease. Dysplasia of the nail unit (most often the thumb) is seen in $95-100 \%$ of patients. Triangular lunula, hypoplasia, splitting or absent nails are typical abnormalities ${ }^{(41)}$.

\section{Pachyonychia congenita}

Pachyonychia congenita (PC) is a disorder of keratinisation, which usually develops within the first 3 years of life and is inherited as an autosomal dominant trait (mutations of KRT6A, KRT6B, KRT6C, KRT16 and KRT17). Nails, palms and plantar foot surfaces are usually involved. Although several subtypes of the disease have been distinguished, they are all characterised by a triad of symptoms: hypertrophic dysplasia of nails, plantar keratoderma and pain. Hyperkeratosis of the nail bed is most often the first symptom of the disease. The nails reach their full length, but they often show dorsal deflection relative to the nail bed due to distal hyperkeratosis, or their growth is prematurely terminated, with partial exposure of the phalanx. Hyperkeratotic lesions (keratoderma) and pain occur during crawling or walking attempts, causing difficulty in moving about and impeding normal development ${ }^{(42,43)}$. Additionally, areas of excessive keratosis involving oral mucosa, keratosis pilaris (especially on the elbows and knees), excess sweating (hands and feet), and, rarely, the so-called natal teeth, may also occur. Since there is no causative treatment for PC, the management of patients primarily involves reduction of the 
nail plate thickness, management of the hyperkeratinised areas and pain control as needed ${ }^{(8,44)}$.

\section{SELECTED MANIFESTATIONS OF SYSTEMIC DISEASES INVOLVING THE NAIL UNIT}

\section{Nail clubbing}

Nail clubbing (watch-glass nails, Hippocratic fingers, drumstick fingers) is a symptom involving alteration of the shape of the nail plate, which resembles a watch-glass (with nail plates overcurved in both longitudinal and transverse axes), and soft tissue hypertrophy. Measurement of the Lovibond's angle ( $>180$ degrees, the angle between the proximal fold and the nail plate), the Curth's angle $(<180$ degrees, an angle at the distal interphalangeal joint), and the Schamroth's window test (1976; absence of the diamond-shaped gap between distal phalanges on opposing fingers) are practically useful ${ }^{(3,8)}$. Nail clubbing is seen in a variety of diseases, such as lung cancers (lung carcinoma in particular), cardiovascular and gastrointestinal diseases, etc. ${ }^{(45)}$. Hypertrophic osteoarthropathy (HOA), which has two forms: primary (pachydermoperiostosis, TouraineSolente-Golé syndrome or idiopathic hypertrophic osteoarthropathy) and secondary (mainly associated with chest cancers or lung abscesses), is a special type of Hippocratic fingers. HOA is characterised by three symptoms: clubbing of the fingers and toes (watch-glass nails), joint pain, and chronic (ossifying) periostitis of the long bones ${ }^{(8,45)}$.

\section{Yellow nail syndrome}

Yellow nail syndrome (YNS) is a very rare condition usually seen in individuals over 50 years of age. It is characterised by a triad of symptoms (two of which are needed for the diagnosis; symptoms from different systems do not occur simultaneously): yellow nail plates of the fingers and toes (pathognomonic for YNS), respiratory symptoms (cough, bronchiectasis, pleural effusion) and lymphoedema. Chronic sinusitis, autoimmune disorders or diseases causing defective lymph drainage (neoplastic processes) are frequently associated with the triad. The manifestations within the nail unit include greenish-yellow colour of the nails (opaque and hard), slowed rate of growth (usually half of the normal growth rate) and increased thickness of the nail plate, absent cuticle, and enhanced transverse curvature (which results in onycholysis ${ }^{(7,46)}$.

\section{CONCLUSIONS}

Diseases of the nail unit are often underestimated by doctors, and only a small group of specialists are familiar with proper onychological terminology. The knowledge presented in this paper is intended to help establish a constructive dialogue between specialists in skin diseases and general practitioners, who provide all types of primary care for

\section{Conflict of interest}

The authors do not report any financial or personal connections with other persons or organisations, which might negatively affect the contents of this publication and/or claim authorship rights to this publication.

\section{References}

1. Wang E, de Berker D, Christiano AM: Biology of hair and nails. In: Bolognia JL, Schaffer JV, Cerroni L (eds.): Dermatology. $4^{\text {th }}$ ed., Saunders Elsevier, 2018: 1144-1162.

2. Jaworek A, Zalewski A, Wojas-Pelc A: Wybrane aspekty immunologii aparatu paznokciowego. Derm Dypl 2019; 10 (5): 24-31.

3. Mukhopadhyay AK: History of nail diseases. In: Singal A, Neema S, Kumar P (eds.): Nail Disorders. A Comprehensive Approach. $1^{\text {st }}$ ed., CRC Press, 2019 (e-book).

4. Żaba R: Historia mikologii poznańskiej - prof. dr hab. med. Jan Alkiewicz. Post Dermatol Alergol 2003; 20: 336-339.

5. Jaworek A, Wojas-Pelc A: Wybrane korelacje anatomiczno-kliniczne zmian w obrębie narządu paznokciowego. Derm Dypl 2019; 10 (3): 45-49.

6. Yamamoto T: Psoriatic arthritis: from a dermatological perspective. Eur J Dermatol 2011; 21: 660-666.

7. Grover C, Bansal S: The nail as an investigative tool in medicine: what a dermatologist ought to know. Indian J Dermatol Venereol Leprol 2017; 83: 635-643.

8. Tosti A, Piraccini BM: Nail disorders. In: Bolognia JL, Schaffer JV, Cerroni L (eds.): Dermatology. $4^{\text {th }}$ ed., Saunders Elsevier, 2018: 1203-1219.

9. Braswell MA, Daniel CR $3^{\text {rd }}$, Brodell RT: Beau lines, onychomadesis, and retronychia: a unifying hypothesis. J Am Acad Dermatol 2015; 73: 849-855.

10. Lee YJ, Yun SK: Unilateral Beau's lines associated with a fingertip crushing injury. J Dermatol 2005; 32: 914-916.

11. Hardin J, Haber RM: Onychomadesis: literature review. Br J Dermatol 2015; 172: 592-596.

12. Jaworek A, Pełka K, Wojas-Pelc A: Spełzanie płytek paznokciowych - istotny problem diagnostyczny. Derm Dypl 2017; 7 (6): 40-43.

13. Chiu HH, Liu MT, Chung WH et al.: The mechanism of onychomadesis (nail shedding) and Beau's lines following hand-footmouth disease. Viruses 2019; 11. pii: E522.

14. Iorizzo M, Pazzaglia M, Piraccini BM et al.: Brittle nails. J Cosmet Dermatol 2004; 3: 138-144.

15. Baran R, Schoon D: Nail fragility syndrome and its treatment. J Cosmet Dermatol 2004; 3: 131-137.

16. Jadhav VM, Mahajan PM, Mhaske CB: Nail pitting and onycholysis. Indian J Dermatol Venereol Leprol 2009; 75: 631-633.

17. Kim M, Jung HY, Kang JH et al.: Elkonyxis associated with habit-tic deformity: two case reports. J Dermatol 2014; 41: 772-773.

18. Gopal V, Shenoy MM: Nail evaluation in internal diseases: an indispensable exercise. AMHS 2017; 5: 269-274.

19. Walker J, Baran R, Vélez $\mathrm{N}$ et al.: Koilonychia: an update on pathophysiology, differential diagnosis and clinical relevance. J Eur Acad Dermatol Venereol 2016; 30: 1985-1991.

20. Razmi TM, De D: Bead retention test in koilonychia. Indian J Dermatol Venereol Leprol 2019; 85: 229-230.

21. Haber JS, Chairatchaneeboon M, Rubin AI: Trachyonychia: review and update on clinical aspects, histology, and therapy. Skin Appendage Disord 2017; 2: 109-115.

22. Jacobsen AA, Tosti A: Trachyonychia and twenty-nail dystrophy: a comprehensive review and discussion of diagnostic accuracy. Skin Appendage Disord 2016; 2: 7-13.

23. Zaias N, Escovar SX, Zaiac MN: Finger and toenail onycholysis. J Eur Acad Dermatol Venereol 2015; 29: 848-853.

24. Aghazadeh N, Sotoudeh S, Ghanadan A et al.: Onycholysis and subungual purpura of nails. Int J Dermatol 2019; 58: 425-427.

25. Dika E, Starace M, Patrizi A et al.: Squamous cell carcinoma of the nail unit: a clinical histopathologic study and a proposal for classification. Dermatol Surg 2019; 45: 365-370. 
26. Chávez-López MA, Arce-Martínez FJ, Tello-Esparza A: Muehrcke lines associated to active rheumatoid arthritis. J Clin Rheumatol 2013; 19: 30-31.

27. Witkowska AB, Jasterzbski TJ, Schwartz RA: Terry's nails: a sign of systemic disease. Indian J Dermatol 2017; 62: 309-311.

28. Oanță A, Iliescu V, Țărean S: Half and half nails in a healthy person. Acta Dermatovenerol Croat 2017; 25: 303-304.

29. Haber R, Khoury R, Kechichian E et al.: Splinter hemorrhages of the nails: a systematic review of clinical features and associated conditions. Int J Dermatol 2016; 55: 1304-1310.

30. Sechi A, Savoia F, Patrizi A et al.: Dermoscopy of subungual red comets associated with tuberous sclerosis complex. Pediatr Dermatol 2019; 36: 408-410.

31. Mendiratta V, Jain A: Nail dyschromias. Indian J Dermatol Venereol Leprol 2011; 77: 652-658.

32. Bae SH, Lee MY, Lee JB: Distinct patterns and aetiology of chromonychia. Acta Derm Venereol 2018; 98: 108-113.

33. Leung AKC, Lam JM, Leong KF et al.: Melanonychia striata: clarifying behind the Black Curtain. A review on clinical evaluation and management of the 21st century. Int J Dermatol 2019; 58: 1239-1245.

34. Morand A, Morand JJ: [Pseudomonas aeruginosa in dermatology]. Ann Dermatol Venereol 2017; 144: 666-675.

35. Chiriac A, Brzezinski P, Foia L et al.: Chloronychia: green nail syndrome caused by Pseudomonas aeruginosa in elderly persons. Clin Interv Aging 2015; 10: 265-267.

36. Catalfo P, Musumeci ML, Lacarrubba F et al.: Congenital malalignment of the great toenails: a review. Skin Appendage Disord 2018; 4: 230-235.
37. Wang CY, Kern J, Howard A: Late-onset malalignment of the great toenails. Australas J Dermatol 2019; 60: 315-317.

38. Cabete J, Lencastre A: And next... Adnexa: congenital hypertrophy of the lateral nail folds of the hallux. Eur J Dermatol 2016; 26: 328-329.

39. Rosales Figueroa JD, Chang P: Brachyonychia associated with acroosteolysis in chronic kidney disease: how phalange shape influences nail morphology. Skin Appendage Disord 2018; 4: 264-267.

40. Richert B, André J: Nail disorders in children: diagnosis and management. Am J Clin Dermatol 2011; 12: 101-112.

41. Witzgall R: Nail-patella syndrome. Pflugers Arch 2017; 469: 927-936.

42. Eliason MJ, Leachman SA, Feng BJ et al.: A review of the clinical phenotype of 254 patients with genetically confirmed pachyonychia congenita. J Am Acad Dermatol 2012; 67: 680-686.

43. O'Kane AM, Jackson CP, Mahadevan M et al.: Laryngeal manifestations of pachyonychia congenita: a clinical case and discussion on management for the otolaryngologist. J Laryngol Otol 2017; 131 (S2): S53-S56.

44. DeKlotz CMC, Schwartz ME, Milstone LM: Nail removal in pachyonychia congenita: patient-reported survey outcomes. J Am Acad Dermatol 2017; 76: 990-992.

45. Vandemergel X, Renneboog B: Prevalence, aetiologies and significance of clubbing in a department of general internal medicine. Eur J Intern Med 2008; 19: 325-329.

46. Kuwahara N, Homma T, Sagara H: Yellow nail syndrome with complete triad. Neth J Med 2019; 77: 86. 